\title{
Milk Preservation by Using HVEF
}

\author{
Achal Mogla ${ }^{1}$, Hemant ${ }^{1 *}$ and D. K. Chaturvedi ${ }^{2}$ \\ ${ }^{1}$ Department of Dairy Technology, Faculty of Science, \\ ${ }^{2}$ Department of Electrical Engineering, Faculty of Engineering, Dayalbagh Educational \\ Institute, Dayalbagh, Agra-282005, India \\ *Corresponding author
}

\section{A B S T R A C T}

\section{Keywords}

Milk shelf life,

Bacterial Load, High voltage, microbial growth

Article Info

Accepted:

05 June 2020

Available Online:

10 July 2020
Different types of Milk preservation techniques are there to increase the shelf life of milk. The most commonly used methods are Pasteurization, Sterilization and Ultra High temperature Treatment. The common thing in above 3 methods is Thermal Heat treatment. Milk when exposed to heat can alter the functional properties of milk specifically in terms of milk nutritional value. Therefore, this has led to the development of non-thermal food preservation techniques. This paper deals with High Voltage Electric Field (HVEF) method of preservation of milk wherein milk was subjected to HV upto $40 \mathrm{kV} / \mathrm{cm}$ field in between two electrodes to increase its shelf life. Reason for using this technique was that milk got spoiled during improper storage of milk. When milk was stored at low temperature bacterial loads were increased depending on the interval of storage. In this paper, the bacterial load in milk is studied with and without HVEF, which is the main cause for the spoilage of milk.

\section{Introduction}

Milk has a vital nutritional part in the diet all around the globe, especially for growing young children. Milk is an important source of protein, phosphorus, calcium, magnesium and fat-soluble and some other vitamins and minerals including iodine. Lactose in milk is involved in regulating osmotic pressure but an additional role in facilitating calcium absorption in infants has been suggested (23). The studies also show the negative correlation between milk consumption and childhood diseases. There is no substitute of mothers' milk for infants. Milk also improve the immune system of infants, improve childhood health and nutritional status (24).

India is one of the largest the world's milk producing Nations since 1998 and has the largest bovine population in the world. Milk production in India during the period 1950-51 to 2018-19, has increased from 17 million tonnes to 187.7 million tonnes as compared to 176.3 million tonnes during 2017-18 with a record growth of $6.65 \%$. It is also reported 
that $1.46 \%$ increase in world milk production from 800.2 million tonnes in 2016 to 811.9 million tonnes in 2017. The per capita milk availability of milk in the country which was 130 gram per day during 1950-51 has increased to 374 gram per day in $2017-18$ as the against the world estimation of 294 gram per day during 2017 (1). Fig. 1 shows the Milk production and per capita availability of milk in India in graphical form.

Dairying has become an important secondary source of income for millions of rural families and has assumed the most important role in providing employment and income generating opportunities particularly farmers. Dairy cooperative have been procured daily average of milk about 475.6 Lakh $\mathrm{Kg}$ per day (LKgPD) during 2017-18 as compared to 428.7 lakh kg procured 2016-17 (1).

Liquid milk is the most widely consumed dairy product in India and as per a report released by the IMARC Group the market value is currently around 4167 billion in 2018, exhibiting a Compounded Annual Growth Rate of 13.5\% during 2011-2018 (2). With such a huge quantity of milk being procured, the next biggest challenge is the preservation of milk.

Temperature is a major factor, which influences microbial growth. The role of low temperature (refrigeration) is well recognized in maintaining the quality of preserved milk. The temperature between $30^{\circ} \mathrm{C}$ to $40^{\circ} \mathrm{C}$ is quite favorable for many bacteria. However, some bacteria such as psychrotrophic and psychrophilic can grow at low temperatures down to $0^{\circ} \mathrm{C}$. Listeria monocytogenes is a pathogenic type bacterium and grow at very low temperatures. However, in milk there is a diverse microflora, which would be outgrown by the psychrotrophic spoilage bacteria, such as members of the genera, Pseudomonas, Bacillus and Micrococcus. Some recent field studies that have been carried out with raw milk treated by the LP-s and stored at 30$35^{\circ} \mathrm{C}$ showed a consistent inhibition of microbial growth for 4-7 hours as shown in Table 1.

The milk of all mammals contains the lactoperoxidase enzyme. This LP-s enzyme levels are different in different animals' milk (21). The literature shows that the preservation time of milk is temperature dependent and also dependent on type of milk such as cow and buffalo milk, goat and sheep milk, camel milk. In the camel milk, the activation of the LP-s may induce a longerlasting bacteriostatic effect than in cow's milk due to the presence of higher levels of other indigenous antimicrobial components (5).

To increase the preservation time of milk different preservation techniques are used. The preservation techniques can be classified based on heat treatment as thermal and nonthermal type, based on use of chemical preservatives or non-chemical preservatives to control the spoilage of milk. The thermal technique includes high temperature techniques and low temperature or refrigeration techniques.

In both these techniques large amount of energy is required depending on the quantity of milk. The milk preservation treatment includes pasteurization and microfiltration (with or without pasteurization), bactofugation, high-pressure treatment (400$800 \mathrm{MPa})$ to inactivate microorganisms and use of chemical preservatives (including salting at levels of $3-12 \%$ ). These techniques require expensive equipments and cannot be widely used in small scale dairy production or domestic milk preservation.

The chemical preservation techniques are not for human health. These techniques also change the nutrition value of milk. Other 
techniques of milk preservation are low temperature (refrigeration), but in this method huge amount of energy is consumed if climatic temperature is high as in summers. Therefore, the need of the hour is to provide an alternative non thermal pasteurization process and low energy consumption technique.

Milk is a perishable food. It has limited shelf life depending on the kind of treatment it has been subjected to. Milk fat is present in the form of Milk Fat Globules and it is surrounded by a membrane and it is collectively known as Milk Fat Globule Membrane (MFGM). It contains proteins, glycoproteins, polarlipids, phospholipids, enzymes, and cholesterol. The function of the membrane is to provide emulsion stability and inhibit the coalescence of milk fat globules (MFGs), thus preventing triglyceride hydrolysis through native or bacterial lipases.

The pasteurization is a thermal treatment method for increasing the shelf life of milk. But at the same time there is a danger of modification of milk components and they can also alter the functional properties of milk proteins.

Therefore the need of the hour is to provide an alternative non thermal pasteurization process. Pulsed electric fields are an emerging technology that is now being used in the food and the dairy industry. It has been shown in multiple studies to effectively kill multiple food microorganisms (3).

In the past various works have been done related to the effect of pulsed electric field processing on the functional properties of bovine milk and also various other milk products made from it. In this the food is exposed to electric fields between electrodes within a treatment chamber and the shelf life of milk can be increased. Pasteurized Milk was treated to a pulsed electric field and its shelf life was increased (4). There are various factors involved in the preservation of milk which are microbial factors and nutrinal factors as shown in Fig. 2.

In this paper the shelf life of milk has been increased by using HVEF which includes the effect of high electric field on raw milk and its bacterial load is studied.

\section{HVEF method of preservation}

The HVEF process is more energy efficient since the microbial inactivation is achieved at ambient or moderate temperature by the application of short bursts of HVEF in raw milk. The raw milk is placed between two electrodes where in it is exposed to HVEF of $40 \mathrm{KV}$ for a short duration of 5 minute for a maximum period of upto 5 times. Experimental set up is shown in Figure 2.

\section{Specification of the equipment used is as under}

Step up $100 \mathrm{kV}$ transformer

1000 pF $100 \mathrm{kV}$ capacitor

Treatment Chamber

Different shapes of electrodes (spherical, point, plate, etc).

\section{Treatment of milk and observations}

Raw milk sample was taken and treated to a magnitude of electric field of $40 \mathrm{kV} / \mathrm{cm}$. The smell, taste, and physical appearance of the raw milk remained the same and there were no physical changes that took place in the milk. But at the same time the microbial load was found to be reduced after this treatment as mentioned in Table 1. Since milk is a highly perishable item, it gets spoiled easily within a certain time interval if proper storage of milk is not there in cold temperatures of 4 $\mathrm{C}$ or less. The spoilage can be in terms of both 
bacterial and chemical changes. The microbes are generally not seen by naked eye, but they have a capacity to grow and multiply very fast with methods like binary fission.

They can be enumerated by using the SPC (standard plate count) method. With the increase in the favorable conditions some Yeast \& Mould can also grow along with the Pathogenic \& Spoilage causing microorganisms like Colliform, Bacteria, and Escherichia Coli\& Salmonella. It was found that when raw milk was subjected to this treatment there was a decrease in the microbial growth as compared to the raw milk that was not and there was also an increase in shelf life of around 7 to 10 days at a temperature of $4 \mathrm{C}$ or less (Table 1 and Table 2).

Table.a Maintaining Milk quality from Lactoperoxidase (LP-s) at different temperatures

\begin{tabular}{|l|l|l|}
\hline Temperature $\left({ }^{\circ} \mathrm{C}\right)$ & Preservation time (hours) & Reference \\
\hline $31-35$ & $4-7$ & Ponce et al., 2005 \\
\hline 30 & $7-8$ & CAC1991b \\
\hline 25 & $11-12$ & CAC1991b \\
\hline 20 & $16-17$ & CAC1991b \\
\hline 15 & $24-26$ & CAC1991b \\
\hline 4 & $5-6$ days & $\begin{array}{l}\text { Zapico } \text { et al., 1995; } \\
\text { Lin and Chow 2000 }\end{array}$ \\
\hline
\end{tabular}

Table.1 HVEF treated raw milk

\begin{tabular}{|l|l|l|l|l|l|l|c|}
\hline Sample & Test & Dilution & Mode & Prepared on & By & Result & Validation \\
\hline $\begin{array}{l}\text { Treated } \\
\text { Milk }\end{array}$ & AC & $1 / 400$ & $40-48 \mathrm{~h}$ & $\begin{array}{l}\text { Thu 02/13/2020 } \\
01: 14 \mathrm{PM}\end{array}$ & bmx_admin & $\begin{array}{l}>4.9 \text { E5 } \\
\text { CFU/g }\end{array}$ & $\checkmark$ \\
\hline $\begin{array}{l}\text { Treated } \\
\text { Milk }\end{array}$ & AC & $1 / 400$ & $40-48 \mathrm{~h}$ & $\begin{array}{l}\text { Thu 02/13/2020 } \\
01: 14 \mathrm{PM}\end{array}$ & bmx_admin & $\begin{array}{l}>4.9 \mathrm{E5} \\
\text { CFU/g }\end{array}$ & $\checkmark$ \\
\hline $\begin{array}{l}\text { Treated } \\
\text { Milk }\end{array}$ & AC & $1 / 400$ & $40-48 \mathrm{~h}$ & $\begin{array}{l}\text { Thu 02/13/2020 } \\
01: 14 \mathrm{PM}\end{array}$ & bmx_admin & $\begin{array}{l}=1.7 \mathrm{E5} \\
\text { CFU/g }\end{array}$ & $\checkmark$ \\
\hline $\begin{array}{l}\text { Treated } \\
\text { Milk }\end{array}$ & AC & $1 / 400$ & $40-48 \mathrm{~h}$ & $\begin{array}{l}\text { Thu 02/13/2020 } \\
01: 14 \mathrm{PM}\end{array}$ & bmx_admin & $\begin{array}{l}=2.0 \mathrm{E} 4 \\
\text { CFU/g }\end{array}$ & $\checkmark$ \\
\hline $\begin{array}{l}\text { Treated } \\
\text { Milk }\end{array}$ & AC & $1 / 400$ & $40-48 \mathrm{~h}$ & $\begin{array}{l}\text { Thu 02/13/2020 } \\
01: 14 \mathrm{PM}\end{array}$ & bmx_admin & $\begin{array}{l}\text { bm E3 } \\
\text { CFU/g }\end{array}$ & $\checkmark$ \\
\hline
\end{tabular}


Table.2 Untreated raw milk

\begin{tabular}{|c|c|c|c|c|c|c|c|}
\hline Sample & Test & Dilution & Mode & Prepared on & By & Result & Validation \\
\hline $\begin{array}{l}\text { Raw } \\
\text { Milk }\end{array}$ & $\mathrm{AC}$ & $1 / 400$ & $40-48 h$ & $\begin{array}{l}\text { Thu } 02 / 13 / 2020 \\
01: 39 \mathrm{PM}\end{array}$ & bmx_admin & $>4.9 \mathrm{E} 5 \mathrm{CFU} / \mathrm{g}$ & $\checkmark$ \\
\hline $\begin{array}{l}\text { Raw } \\
\text { Milk }\end{array}$ & $\mathrm{AC}$ & $1 / 400$ & $40-48 \mathrm{~h}$ & $\begin{array}{l}\text { Thu } 02 / 13 / 2020 \\
01: 41 \mathrm{PM}\end{array}$ & bmx_admin & $>4.9 \mathrm{E} 5 \mathrm{CFU} / \mathrm{g}$ & $\checkmark$ \\
\hline $\begin{array}{l}\text { Raw } \\
\text { Milk }\end{array}$ & $\mathrm{AC}$ & $1 / 400$ & $40-48 h$ & $\begin{array}{l}\text { Thu } 02 / 13 / 2020 \\
01: 42 \mathrm{PM}\end{array}$ & bmx_admin & $=6.8 \mathrm{E} 4 \mathrm{CFU} / \mathrm{g}$ & $\checkmark$ \\
\hline $\begin{array}{l}\text { Raw } \\
\text { Milk }\end{array}$ & $\mathrm{AC}$ & $1 / 400$ & $40-48 \mathrm{~h}$ & $\begin{array}{l}\text { Thu } 02 / 13 / 2020 \\
01: 42 \mathrm{PM}\end{array}$ & bmx_admin & $=3.5 \mathrm{E} 3 \mathrm{CFU} / \mathrm{g}$ & $\checkmark$ \\
\hline $\begin{array}{l}\text { Raw } \\
\text { Milk }\end{array}$ & $\mathrm{AC}$ & $1 / 400$ & $40-48 h$ & $\begin{array}{l}\text { Thu } 02 / 13 / 2020 \\
01: 43 \mathrm{PM}\end{array}$ & bmx_admin & $=2.8 \mathrm{E} 3 \mathrm{CFU} / \mathrm{g}$ & $\checkmark$ \\
\hline
\end{tabular}

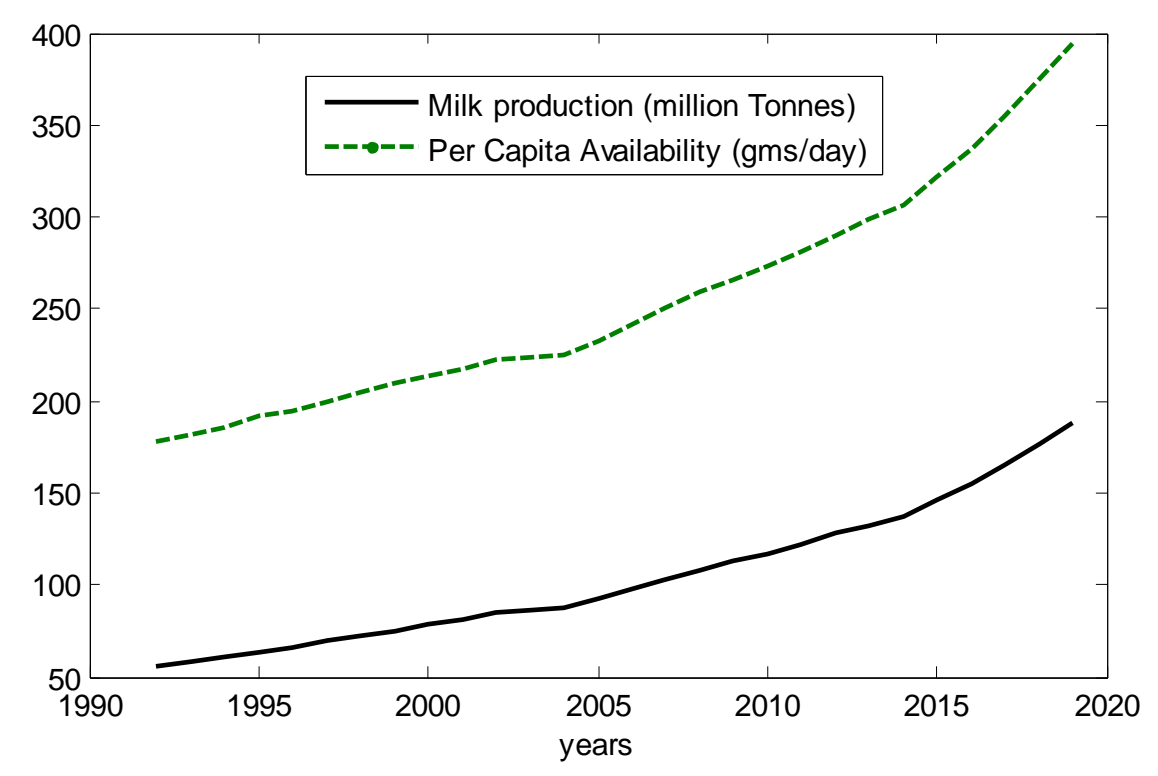

Fig.1 Trends of milk production and per capita availability

\section{Important factors in Milk Preservation}

\section{MICROBIAL FACTORS}

- Reduction of the bacterial load

- Killing of all the spoilage causing microbes

- Killing of all pathogenic microbes

- Killing of all the moulds and fungus

- Killing of all the viruses.

\section{NUTRIONAL FACTORS}

- Less denaturation of protein

- Less reduction of lactose

- No effect on nature of milk total solids

- No effect on colour

- No effect on temperature

- No change in taste

Fig.2 Factors involved in milk preservation 

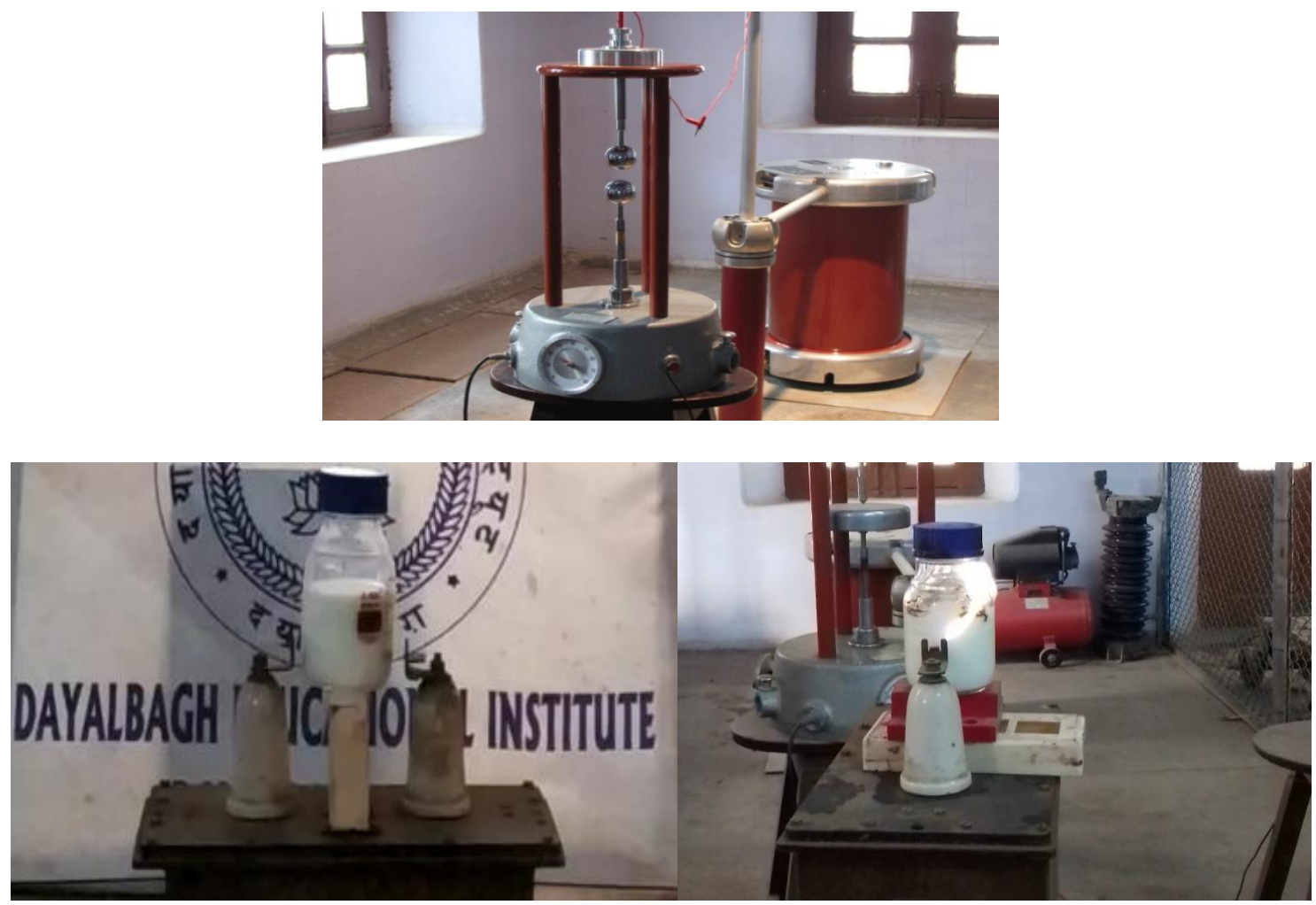

Fig.3 Treating milk with HVEF

The milk consumption in India is increased drastically in last few years and the production is limited. Therefore, it is necessary to preserve milk, so that it cannot spoiled. In this direction, paper proposes the milk preservation using HVEF technique. The study shows the effect of HVEF by measuring bacterial load ( microbial growth) in milk. It was found that when raw milk was subjected to this treatment there was a decrease in the microbial growth as compared to the raw milk that was not treated. Hence, there is an increase in shelf life of treated milk.

\section{References}

1. www.nddb.coop/information.statistics.

2. www.imarcgroup.com/liquid-milkmarket-india

3. Sharma P, Bremer P, Oey I and Everett D W (2014) Bacterial inactivation in whole milk using pulsed electric field processing International Dairy Journal 35(1),49-56.

4. Sepulveda D.R, et .(2005), Production of extended-shelf life milk by processing pasteurized milk with pulsed electric fields J Food Engineering.2005;67(1-2) 81-86.

5. Chaturvedi, D. K. (2020). Wheat Preservation Using Electric, Field. Int.J. Curr. Microbiol. App. Sci. 9(1): 18611869.

DOI: https://doi.org/10.20546/ijcmas.202 0.901 .208

6. Neelam Upadhyay (2014), Preservation of Milk and Milk Products for Analytical Purposes, Food Reviews International 30(3), June 2014, DOI: $10.1080 / 87559129.2014 .913292$

7. Nuwemuhwezi Gershom, Edward Ssemakula. Traditional Methods of Milk Processing and Preservation by Local Farmers in Kashongi Sub County Kiruhura District. American Journal of Science, Engineering and Technology. Vol. 2, No. 2, 2017, pp. 62-71.

8. Min S, Evrendilek GA, Zhang QH. Pulsed electric fields:processing system, 
microbial and enzyme inhibition, and shelf-life extension of foods. IEEE Transactions on Plasma Science. 35(1):59-73.

9. Cardello AV, Schutz HG, Lesher LL. Consumer perceptions of foods processed by innovative and emerging technologies: A conjoint analytic study. Innovative Food Science \& Emerging Technologies. 2007;8(1):73-83.

10. Williams, P.; Garry, E.; Ouattara, G. The effect of Bronopol on the freezing point and impedance of milk samples. Advanced Instruments Inc., Institute Food Technology, 2007, 1-6.

11. Elizondo, J.; Aldunate, A.; Ezcurra, P.; Ga llego, I.; Saigos, E.; Ulayar, E.; Izco, J.M. Efficiency of the proportion of azidiol on preservation of ewe's milk samples for analysis. Food Control 2007, 18, 185-190.

12. Benda, $\mathrm{P}$. The effect of some preservatives on natural microflora in milk samples. Vet. Med. (Prague) 1995, 40, 359-364.

13. Rapp, M.; Muench, S. Newly developed liquid preservation agents for milk. Dtsch. Molkerei Ztg. 1984, 105, 1264-1272.

14. Dawood, A.E.; Naghmoush, M.R.; Nofel, A.A. The effect of certain additives on acidity and formal number of milk. Ala. J. Agric. Res. 1974, 22, 73-77. (Cited in Dairy Sci. Abstr. 1976, 38, 8238.)

15. Bansal, A.; Singhal, O.P. Preservation of milk samples with formalin-Effect on acidity. Indian J. Dairy Sci. 1991, 44, 573-576.

16. CAC. 1991b. Guidelines for the preservation of raw milk by use of the lactoperoxidase system (CAC GL 13/91).

17. Ponce, C.P., Armenteros, A. M., Villoch, C., Montes de Oca, N. \& Carreras, J. 2005. Evaluation of microbiological and chemical risks of the lactoperoxidase system activation in raw milk. Available at http://bvs.sld.cu/uats/rtv_files/2005/rtv050 5.htm

18. Zapico, P., Gaya, P., Nunez, M. \& Medina, M. 1995. Activity of goat's milk lactoperoxidase system on Pseudomonas fluorescens and Escherichia coli at refrigeration temperature. Journal of Food Protection, 58: 1136-1138.

19. Lin, G. \& Chow, C. 2000. Studies on the lactoperoxidase system and its use in extending the storage period of cow's raw milk. Journal of the Chinese Society of Animal Science, 29: 89-99.

20. Ramet, J.P. 2001. The technology of making cheese from camel milk (Camelus dromedarius). FAO Animal Production and Health Paper 113. FAO, Rome.

21. Fonteh, F.A., Grandison, A.S. \& Lewis, M.J. 2002. Variations of lactoperoxidase activity and thiocyanate content in cows' and goats' milk throughout lactation. Journal of Dairy Research, 69: 401-409.

22. Garrow, J.S., James, W.P.T. \& Ralph, A. 2000. Human Nutrition and Dietetics 10th Edition. p.452. London: Churchill Livingstone.

23. Abrams, S.A., Griffin, I.J. \& Davila, P.M. 2002. Calcium and zinc absorption from lactose containing and lactose-free infant formulas. American Journal of Clinical Nutrition, 76: 442-6.

24. Scrimshaw, N.S. \& San Giovanni, J.P. 1997. Synergism of nutrition, infection, and immunity: an overview. American Journal of Clinical Nutrition, 66: 464S$477 \mathrm{~S}$.

25. Coralie Dupas, et al., Plants: A natural solution to enhance raw milk cheese preservation?, Food Research International, Volume 130, April 2020, DOI:

https://doi.org/10.1016/j.foodres.2019.108 883. 


\section{How to cite this article:}

Achal Mogla, Hemant and Chaturvedi. D. K. 2020. Milk Preservation by Using HVEF. Int.J.Curr.Microbiol.App.Sci. 9(07): 537-544. doi: https://doi.org/10.20546/ijcmas.2020.907.059 